PERSPECTIVES IN A PANDEMIC 



\section{PERSPECTIVES IN A PANDEMIC}

Kevin M. Cahill, M.D.

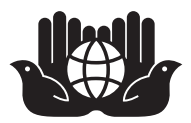

Refuge Press, New York, 2020 
Copyright $\odot 2020$

The Center for International Humanitarian Cooperation

Fordham University IHA Book Series

All rights reserved.

No part of this book may be reproduced or utilized in any form or by any means, electronic or mechanical, including photocopying and recording, or by any information storage and retrieval system without permission in writing from the publishers.

ISBN \#13: 978-0-8232-9498-5

All royalties from this book go to the training of humanitarian workers.

Cover design: Mauro Sarri Cover Image courtesy of NASA

The logo of the CIHC, used as a printer's device to separate each section, symbolizes the unity of healing hands in relief work with the doves for peace.

Printed in the United States of America. 


For the Marias Aramanda 
